\title{
PREVALENCE AND PREDICTING RISK FACTORS OF OVERWEIGHT AND OBESITY AMONG PRIMARY SCHOOL PUPILS IN RAMADI, IRAQ
}

\author{
Ahmed K. Al-Delaimy ${ }^{1}$, Mahasin Ali Al-Taha ${ }^{1}$ and Mustafa Ali Mustafa Al-Samarraie ${ }^{1}$ \\ ${ }^{1}$ Family and Community Medicine, Medical College, Anbar University, Iraq
}

Corresponding author: Ahmed K. Al-Delaimy ${ }^{1}$

Email: med.ahmed.soofi@uoanbar.edu.iq

\begin{abstract}
Childhood obesity is increasing at a dramatic rate that it can be considered a pandemic. The aim of this study is to address the prevalence of obesity among primary pupils in Ramadi City and to determine different risk factors associated with obesity among these children. A cross-sectional study was carried out and random selections of three primary schools were taken at the center of Ramadi City. A total of 512 pupils were included in this study (232 male and 280 female) to include all eligible children age 6 to 12 years. The study period was during the study year 20182019. Anthropometric measurements of height and body weight were carried out using standardized methods. The prevalence of overweight was $15.4 \%$ (85-97th percentile) and obese (= $\geq 97$ th percentile) was $13.3 \%$. The Mean BMI percentile of pupils was $17.8 \pm 3.9$, range (11.3-37.5). Risk factors highly associated with overweight and obesity $(P<0.05)$ were gender, increased age, mother education, taking breakfast and fruits, sitting in front of the TV. While daily vegetable intake and type of feeding at first 6 months after delivery were not found to be significantly associated with overweight and obesity in our study. The prevalence of overweight and obesity primary school children in this study are at an alarming level and the disease trends are growing in this country. Preventive pupils health action is required for this age group.
\end{abstract}

Keywords: Obesity, prevalence, risk factors, pupils

\section{INTRODUCTION}

The prevalence of childhood overweight is increasing at a dramatic rate that it can be considered a pandemic ${ }^{(1)}$. Childhood obesity has become a major public health concern in developing countries (2). In the Eastern Mediterranean Region alone, the prevalence of obesity and overweight among school children ranged from $7 \%$ to $45 \%(3,4)$. In a study done recently in Jordan shows the prevalence rate of obese and overweight in schoolchildren were 13\% and $12 \%$ respectively ${ }^{(5)}$.

Lifestyle modification in this region towards western society food consumption has been linked to this health problem ${ }^{(2)}$. Although some studies showed that both risk factors race and socioeconomic status of the family have an inconsistent association with the disease' prevalence, at the same time other studies showed that both environmental and genetic factors have an association with its prevalence ${ }^{(6)}$. Physical inactivity as a child could result in physical inactivity as an adult ${ }^{(7)}$. Many children fail to exercise because they are spending time doing stationary activities such as playing video games or watching $\mathrm{TV}^{(8)}$.Alkhawaldeh $\mathrm{A}$ et al, 2017 in his study showed that regular recording of adolescence exercise and food intake could be one of the important approaches to manage obesity and overweight in adolescence ${ }^{(9)}$. Obese children often suffer from teasing by their peers and may lead to low self-esteem and depression ${ }^{(10)}$.
Monitoring and knowing the prevalence of obesity in a region is important to plan health strategies for prevention and to provide care to the population ${ }^{(11)}$. Therefore this study aims to address the prevalence of overweight and obesity among primary school pupils, also to determine the risk factors associated with obesity among these children.

\section{METHODS}

Ramadi is a city located about 110 kilometres west of Baghdad. It is the capital of Al Anbar Governorate with a population of approximately 375,000 . About 90 governmental primary schools present in the governorate distributed in the centre and periphery of the city. Ethical approval was sought from Anbar University and General Directorate of Education at Ramadi City, Anbar governorate. Signed informed consent was taken from parents, and they have the right to participate or refuse/withdraw from the survey.

A cross-sectional descriptive study was carried out and a simple random sampling was done. Three governmental primary schools were chosen randomly for the study. A list of all schools was marked with a specific number and three schools were chosen randomly through the lottery method to choose samples. A total of 512 pupils were involved in this study (232 male and 280 female) to include all eligible children ages 6 to 12 years. At the same time, pupils less than 6 or more than 12 years of age and those with chromosomal abnormalities and mental 
retardation (with chronic diseases) were excluded from the study. The study period was during the study year 2018-2019. Sample size calculation was carried out and a structured questionnaire form was distributed to school children. Validity and reliability of the questionnaire were done through a pilot test in one of the three schools (about 30 pupil's participants, 5 students from each class), questions were dropped out either it was not answered by parents or irrelevant or culturally not acceptable.

At the same time, two forms of questionnaires were distributed to school children in one of the school with same information but in different formula of questions so as to be filled by parents and the correlation of the two forms were checked. Questionnaire forms were sent to the pupil's house to be signed and filled by parents. Questions were related to dietary habits, breakfast intake, the food selection at home, a food buying at school, hours spent on TV watching, How much he/she drinks soft drinks during a week, any constant schedule of sports lesson for pupils at school, how many times does your child spent at least 20 minutes sporting during a week, and do parents agree of cooperation between school and home for the sake of their children health and weight.

Anthropometric measurements of height and body weight were carried out in schools using standardized methods. For the height measurement, pupils were asked to take off their shoes, stand upright with their head up and the heel, buttock, and occiput against the wall. Height was recorded to the nearest $0.5 \mathrm{~cm}$. Weight was also measured using a digital scale to the nearest $0.1 \mathrm{~kg}$ and pupils were asked to take off their shoes and thick clothes, and Body Mass Index (BMI) was calculated using the formula weight $(\mathrm{kg}) /$ height $\left(\mathrm{m}^{2}\right)$.

These measurements were used to determine the $\mathrm{BMI}$, body mass index (BMI) percentile as per the guidelines of the Centers for Disease Control, $2000^{(12,13)}$. CDC growth charts percentiles standard cut-offs were used. Children were categorized into $4 \mathrm{BMI}$ categories and as follows: Thin < 5th percentile or normal $\geq 5$-84th percentile or overweight $85-97$ th percentile or obese $\geq 97$ th.

\section{Statistical analysis}

Analysis of data was carried out using the available statistical package of SPSS-25 (Statistical Packages for Social Sciences- version 25). Data were presented in simple measures of frequency, percentage, mean, standard deviation, and range (minimum-maximum values).

The significance of the difference of different percentages (qualitative data) was tested using the Pearson Chi-square test ( $\chi 2$-test) with an application of Yate's correction or Fisher Exact test whenever applicable. Statistical significance was considered whenever the P-value was equal or less than 0.05 .

\section{RESULTS}

Table 1 shows the socio-demographic and anthropometric characteristics of the study participants. From the total number of 512 pupils, 232 of which $(45.3 \%)$ were males and 280 (54.7\%) were females.

The first six months after delivery, of schoolchildren, were fed $52.3 \%$ breast milk by their mothers, $26.2 \%$ of them were fed artificial bottle feeding, and $21.5 \%$ were both artificial bottle milk feeding and breast milk. The BMI percentile for pupils has divided into four percentiles follows: Thin ( $<5$ th percentile) by $7.2 \%$, normal ( $\geq 5-84$ th percentile) by $64.1 \%$, overweight (85-97th percentile) by $15.4 \%$, obese $(=\geq 97$ th percentile) by $13.3 \%$.

In Table 2, the rate of pupils that usually take breakfast before going to school was $72.5 \%$, and those who take food with them to school were $69.3 \%$, and $62.3 \%$ among those who take food to school provided with sweets, soft drinks, and artificial juices, while only $37.7 \%$ of pupils provide them with protein sandwiches and health food. When families provide their children money to buy food, only $5.7 \%$ of them bought sandwiches of protein source and healthy food and the rest of the $94.3 \%$ bought sugar source including sweets, soft drinks, and artificial juices.

The study shows that for the last week, pupils ate Vegetarian source by only $17.6 \%$ in their main meals. Table 3 shows that for the last week $38.3 \%$ of pupils drink one canned soft drink per day. Pupils eat fast food per week was once by $34.6 \%, 2-3$ times by $12.3 \%$, daily intake by $1.8 \%$ and never buy by $51.4 \%$. Pupils watch TV for three hours and more by $14.8 \%$.

Family rewards their children for any event (birthday, success in school, celebration, obedience) with sweets and candy sugar always by $27.5 \%$ and sometimes by $52 \%$,

Table 4 clarifies the relationship between BMI percentile (overweight and obesity) and various risk factors.

The association was significant with increasing age, gender (males had more obesity prevalence than females, while the female had more overweight than males), history of the disease in a family member, take breakfast before going to school, no fruit intake, increase hours of TV watching. While father education, family income, type of feeding in the first 6 months, food bought from the school canteen, sports class and sweets reward by the family to their 
children was not significantly associated with obesity or overweight in our study.

Table 5 describes the logistic regression of risk factors associated with increased body weight. A highly significant association was found only among $1^{\text {st }}$ and $2^{\text {nd }}$-grade schoolchildren, the OR was 3.5 and 3.1 respectively .Also among pupils who complained about his/her body shape due to overweight was a highly significant association with OR 3.5. Family income was also significant with OR 1.

Table 1: Socio-demographic $\&$ anthropometric characteristics of pupils and feeding practice

\section{Socio-demographic \& anthropometric characteristics of pupils} and feeding practice

\begin{tabular}{|c|c|c|}
\hline Grade/Age in year & $\begin{array}{l}\text { First/6-7 } \\
\text { Second/7-8 } \\
\text { Third/8-9 } \\
\text { Fourth/9-10 } \\
\text { Fifth/10-11 } \\
\text { Sixth/11-12 }\end{array}$ & $\begin{array}{r}62(12.1 \%) \\
158(30.9 \%) \\
93(18.2 \%) \\
70(13.7 \%) \\
64(12.5 \%) \\
65(12.7 \%)\end{array}$ \\
\hline Sex & $\begin{array}{l}\text { Male } \\
\text { Female }\end{array}$ & $\begin{array}{l}232(45.3 \%) \\
280(54.7 \%)\end{array}$ \\
\hline Length $(\mathrm{cm})$ & & Mean \pm SD (Range) $133.5 \pm 12.2(100-170)$ \\
\hline Weight (Kg) & & Mean \pm SD (Range) $32.6 \pm 11.7$ (15-79) \\
\hline Mother education & $\begin{array}{l}\text { Illiteracy } \\
\text { Primary } \\
\text { Secondary } \\
\text { High } \\
\text { Institute and college }\end{array}$ & $\begin{array}{r}95(18.6 \%) \\
204(39.8 \%) \\
113(22.1 \%) \\
33(6.4 \%) \\
67(13.1 \%)\end{array}$ \\
\hline Feeding history & $\begin{array}{l}\text { Breastfeeding Feeding (first } 6 \text { months) } \\
\text { Artificial } \\
\text { Mixed feeding (both artificial and } \\
\text { breast fed) }\end{array}$ & $\begin{array}{l}268(52.3 \%) \\
134(26.2 \%) \\
110(21.5 \%)\end{array}$ \\
\hline BMI percentıle group & $\begin{array}{l}\text { Thin }(<5 \text { th percentile) } \\
\text { Normal }(5-84 \text { percentile) } \\
\text { Overweight }(85-94 \text { percentile) } \\
\text { Obese ( }=>95 \text { percentile) }\end{array}$ & $\begin{array}{r}37(7.2 \%) \\
328(64.1 \%) \\
79(15.4 \%) \\
68(13.3 \%) \\
\text { Mean } \pm \text { SD (Range) } 17.8 \pm 3.9(11.3-37.5)\end{array}$ \\
\hline
\end{tabular}

Table 2: Pupil's attitude towards breakfast, food preference, and money intake and school canteen

\begin{tabular}{|c|c|c|c|}
\hline $\begin{array}{l}\text { Pupil's attitude towards breakfast, fo } \\
\text { canteen }\end{array}$ & reference, and money intake and sch & Num & $(\%)$ \\
\hline $\begin{array}{l}\text { A child taking breakfast before going to } \\
\text { school? }\end{array}$ & Yes & 371 & $(72.5 \%)$ \\
\hline Providing a child with food? & Yes & 355 & $(69.3 \%)$ \\
\hline $\begin{array}{l}\text { If yes, what is the kind of food you } \\
\text { provide him? }\end{array}$ & $\begin{array}{l}\text { Proteins (Healthy food, eggs, cheese, meat) } \\
\text { Sweets \& juices (Chips, chocolates, biscuits, } \\
\text { candy, juices, soft drinks, gum) }\end{array}$ & $\begin{array}{l}134 \\
221\end{array}$ & $\begin{array}{l}(37.7 \%) \\
(62.3 \%)\end{array}$ \\
\hline $\begin{array}{l}\text { Providing the child any money to buy } \\
\text { from the school canteen? }\end{array}$ & Yes & 455 & $(88.9 \%)$ \\
\hline If yes what type of food he/she buy? & $\begin{array}{l}\text { Proteins (Healthy food, eggs, cheese, meat) } \\
\text { Sweets \& juices (Chips, chocolates, biscuits, } \\
\text { candy, juices, soft drinks, gum) }\end{array}$ & $\begin{array}{c}26 \\
429\end{array}$ & $\begin{array}{l}(5.7 \%) \\
(94.3 \%)\end{array}$ \\
\hline $\begin{array}{l}\text { The three main sources of food your } \\
\text { child eats in his/her main meals? }\end{array}$ & $\begin{array}{l}\text { Proteins sandwiches } \\
\text { Carbohydrates } \\
\text { Vegetables }\end{array}$ & $\begin{array}{l}259 \\
163 \\
90\end{array}$ & $\begin{array}{l}(50.6 \%) \\
(31.8 \%) \\
(17.6 \%)\end{array}$ \\
\hline
\end{tabular}


Table 3: Amount of different food intake, TV watching, complains and reward

\begin{tabular}{lcc}
\hline Variables & & No (\%) \\
\hline How many canned soft drinks your child drink per & One canned & $196(38.3 \%)$ \\
day? & Two canned & $144(28.1 \%)$ \\
& $>$ three & $172(33.6 \%)$ \\
How many times your children eat fast-food? & Once & $177(34.6 \%)$ \\
& $2---3$ & $63(12.3 \%)$ \\
& Daily & $9(1.8 \%)$ \\
Hours your child usually watches TV per day? & Never buy & $263(51.4 \%)$ \\
& $<1$ hour & $222(43.4 \%)$ \\
Any complaint from your child about his shape or & $1--2$ & $171(33.4 \%)$ \\
body due to his overweight? & $=>3$ hours & $76(14.8 \%)$ \\
Rewarding your child with candy for any event & Don't watch & $43(8.4 \%)$ \\
(success, birthday, etc.)? & Always & $11(2.1 \%)$ \\
& Sometime & $76(14.8 \%)$ \\
& Never complain & $425(83.0 \%)$ \\
& Always & $141(27.5 \%)$ \\
\end{tabular}

Table 4: Association of risk factors and BMI percentile groups

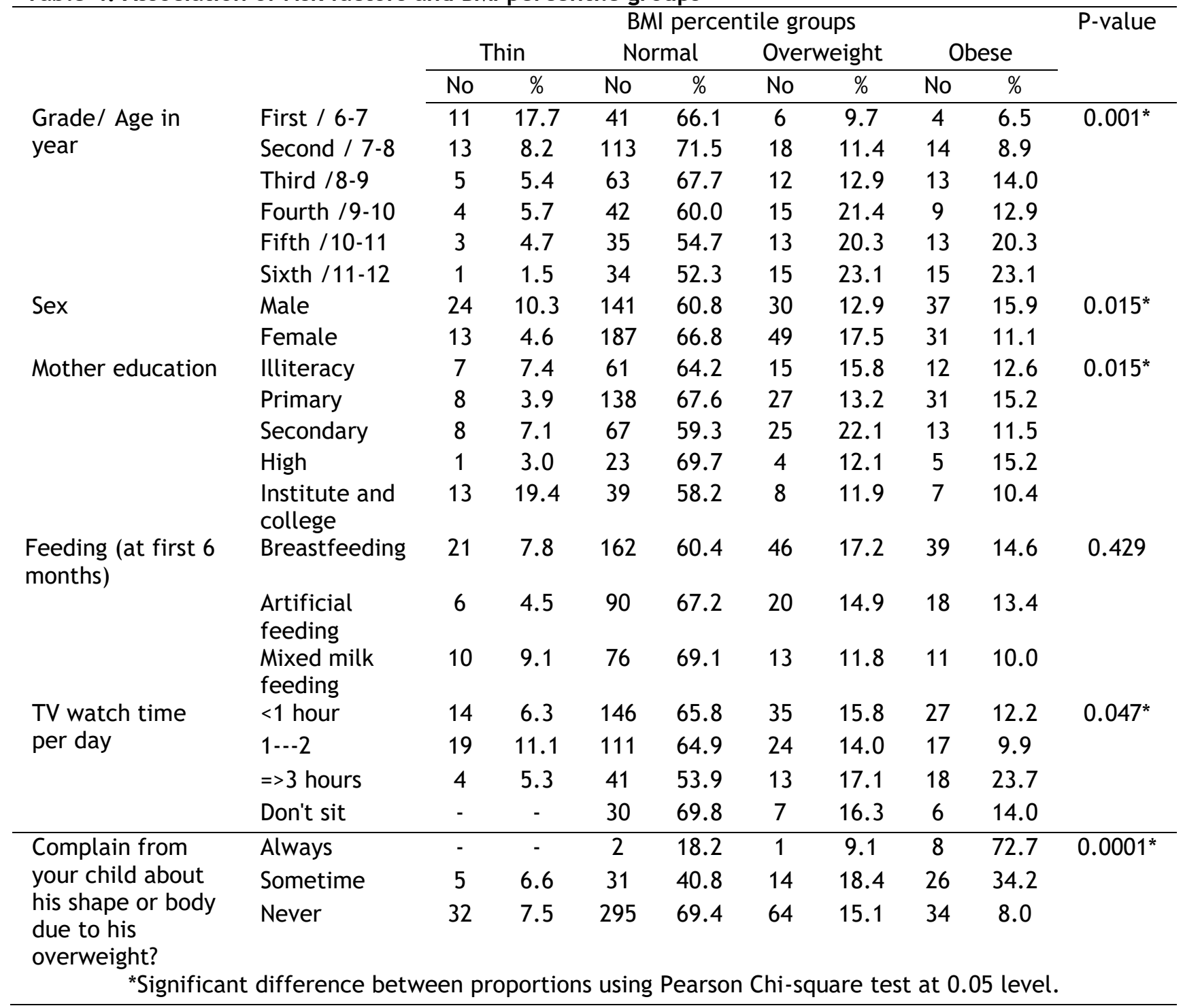


Table( 5) Logistic regression of risk factors associated with increase body weight

\begin{tabular}{lcccccc}
\hline & $\mathrm{B}$ & $\mathrm{df}$ & Sig. & Odds ratio & \multicolumn{2}{c}{$95 \%$ C.I.forodds } \\
Lower & Upper \\
Grades & & & & & & \\
Grade 1 & & 5 & .000 & & & \\
Grade 2 & 1.27 & 1 & .006 & 3.5 & 1.444 & 8.825 \\
Grade 3 & 1.15 & 1 & .001 & 3.1 & 1.566 & 6.392 \\
Grade 4 & 0.59 & 1 & .118 & 1.8 & 0.860 & 3.809 \\
Grade 5 & 0.30 & 1 & .435 & 1.3 & 0.630 & 2.931 \\
& 0.06 & 1 & .868 & 1 & 0.492 & 2.317 \\
Sex & & & & & & \\
Father education & -.054 & 1 & .808 & .948 & .613 & 1.465 \\
Mother education & .054 & 1 & .541 & 1.056 & .887 & 1.257 \\
Family income & .110 & 1 & .265 & 1.117 & .920 & 1.356 \\
Feeding (at first 6 months) & .000 & 1 & .045 & 1.000 & 1.000 & 1.000 \\
Take breakfast & .158 & 1 & .258 & 1.172 & .890 & 1.542 \\
Take food to school & -.357 & 1 & .140 & .700 & .435 & 1.124 \\
Take money to school & -.231 & 1 & .336 & .794 & .496 & 1.270 \\
fruits & .006 & 1 & .987 & 1.006 & .515 & 1.965 \\
Soft drinks & -.179 & 1 & .231 & .836 & .623 & 1.121 \\
School sport &. .165 & 1 & .201 & .848 & .658 & 1.092 \\
Any complaint about shape & .060 & 1 & .827 & 1.062 & .619 & 1.823 \\
Any sweets reward & 1.252 & 1 & .000 & 3.499 & 2.177 & 5.622 \\
Constant & .211 & 1 & .138 & 1.234 & .935 & 1.630 \\
\hline
\end{tabular}

\section{DISCUSSION}

The prevalence of overweight and obesity in our study were $15.4 \%$ and $13.3 \%$ respectively. This result is lower than in other studies in the region including Iraq. A study in Baghdad done by Alredainy and Al-Lami, 2016 showed that the overall prevalence of overweight and obesity was 30.3\%. Also, Zekavat et al, 2014 did a study on

primary school children in Iran and found that the overall prevalence of overweight and obesity was $29.9 \%(14,15)$.

The wide differences in overweight and obesity prevalence between different studies could be explained by the different standard cut-offs used, whether WHO or CDC growth charts; number standard deviations versus percentiles (16).

A significant association between overweight /obesity and the education level of the mother was found in this study. An educated mother has the chance to observe and direct their children towards healthy food and acceptable body shape, this is similar to what reported by Muthuri et al which shows a positive relationship between maternal education and child overweight in Colombia (17). Also Ruiz et al reported that low maternal education in lower economic status countries waives an important risk factor of childhood obesity across several European countries ${ }^{(18)}$. This was incompatible with Vázquez-Nava et al results that showed no association between low educational level mothers and sedentary life in overweight children ${ }^{(19)}$.

Bottle-fed infant versus the breastfed infant and their effect on normal weight or overweight child is still controversial. In this report there was no significant association between obesity and type of feeding during the first six months of life after delivery and a high prevalence of obesity was found among breastfed children. This result is not compatible with another study that shows the protective effect of breastfeeding on child overweight and obesity by creating a low level of insulin in serum (20). Whereas in another study Estévez-González et al show that the percentages of children with normal weight, overweight, and obesity were similar in both groups and there were nobody mass Index differences between children with breastfeeding or without breast feeding during the first six months after delivery ${ }^{(21)}$.

Although there was an increase in the prevalence of overweight $(16.3 \%)$, and obesity $(17.4 \%)$ was noticed among pupils drinking soft drinks ( $>3$ canned drink per day) but there was no significant difference between drinking soft drinks and obesity. Also, there was no significant association between fast food, sports class, sports exercise, and rewarding children by their families and overweight and obesity.

A significant difference was found among the hours spent on TV watching. Channels on TV insert a lot of food commercial advertisements both fast food and sweets advertisement, this motivates children to buy and eat more foods related to adiposity. In addition, the more hours sitting in front of the television screen and mass media the more possible lacking physical activity of children Rosiek et al mentioned in his paper that our eating attitudes are largely affected by commercials and mass media. He suggested that obesity can happen due to the amount of time spent in front of the television ${ }^{(22)}$. 
Multivariate logistic regression analysis shows a significant difference among pupils in the first and second grade. A possible explanation that they are less with regular exercise activity and could spend more time on TV and other activities and behaviors that have no effect on their body weight $(8,23)$. Family income was another possible risk factor in this study that has related to increased body weight among pupils. With more money and income usually families tends to buy more foods including sweets and unhealthy diet. Cesani et al, 2010 in his paper linked the association of increased body weight among children with higher income and good social status (24)

Obese children have a negative effect on their psychological health. Banis et al in his study found that overweight children had fewer selfperceptions, more behavioral problems, and less socially qualified than their non-obese peers ${ }^{(25)}$.

\section{CONCLUSION}

A high prevalence of overweight and obesity among schoolchildren were found in this study. Moreover, unhealthy lifestyle behaviors practiced by schoolchildren played important risk factors in increasing body weight among pupils in this research. Preventive pupils' health action plans, intervention strategies, and analyzing each risk factor associated with obesity are required. Follow up by the primary health centers, school, teachers and parents are recommended to detect any overweight, and obesity in pupils. TV and social media advertisement linked to canned soft drinks, sweets candy, and fast food should be banned by national law of the country, and school canteen set menu should be supervised for selected healthy food provided to schoolchildren.

\section{Acknowledgements:}

Authors would like to acknowledge the General Directorate of Education at Ramadi City, Anbar governorate, Iraq for their cooperation during this study. We are grateful to the headmaster, teachers and staff of Khaled bin Alwaleed, AlAfia, and Ahmed Shawqi primary schools for their help and support. Thanks also to the parents and their children for their participation in this study.

\section{Competing interests}

The authors declare that they have neither competing interests nor financial disclosure.

\section{Funding}

This study was self-funded.

Authors' contributions

All authors read and approved the final manuscript.

\section{REFERENCES}

1. Kimm SY, Obarzanek E. Childhood obesity: a new pandemic of the new millennium. Pediatrics. 2002 Nov 1;110(5):1003-7.

2. Musa DI, Toriola AL, Monyeki MA, Lawal B. Prevalence of childhood and adolescent overweight and obesity in Benue State, Nigeria. Tropical Medicine \& International Health. 2012 Nov;17(11):1369-75.

3. Musaiger AO. Overweight and obesity in the eastern Mediterranean region: prevalence and possible causes. Journal of obesity. 2011 Sep 18;2011.

4. Musa TH, Ali EA, Musa HH, Khan A. Anthropometric parameters of malnutrition in children 5-15 years old in Khartoum State, Sudan. Journal of Public Health and Epidemiology. 2013 Aug 31;5(8):313-8.

5. Batiha AM, Daradkeh S, ALBashtawy M, Aloush S, Al-Natour A, Al Qadire M, Alrimawi I, Khatatbeh M, Al-Awamreh K, Alhalaiqa $F$. The relationship between physical activity and diet, and overweight and obesity, in young people. Nursing children and young people. 2020 May 6;32(3).

6. Adetunji AE, Adeniran KA, Olomu SC, 'et al'. Socio-demographic factors associated with overweight and obesity among primary school children in semi-urban areas of mid-western Nigeria. PloS one. 2019 Apr 3;14(4):e0214570.

7. Ortega FB, Ruiz JR, Castillo MJ, Sjöström M. Physical fitness in childhood and adolescence: a powerful marker of health. International journal of obesity. 2008 Jan;32(1):1-1.

8. Epstein LH, Roemmich JN, Robinson JL, 'et al'. A randomized trial of the effects of reducing television viewing and computer use on body mass index in young children. Archives of pediatrics \& adolescent medicine. 2008 Mar 1;162(3):239-45.

9. Alkhawaldeh A, Khatatbeh M, ALBashtawy M, Al-Awamreh K, Al Qadire M, ALOmari O, Khasawneh B, ALBashtawy B, Alshakh $\mathrm{H}$. Behavioural approaches to treating overweight and obesity in adolescents. Nursing children and young people. 2017 Nov 7;29(9):44-6.

10. Janssen, I., Craig, W. M., Boyce, W. F., \& Pickett, W. (2004). Associations between 
overweight and obesity with bullying behaviors in school-aged children. Pediatrics, 113(5), 1187-1194.

11. Pengpid S, Peltzer K. Overweight and obesity and associated factors among school-aged adolescents in six pacific island countries in Oceania. International journal of environmental research and public health. 2015 Nov;12(11):14505-18.

12. Kuczmarski RJ, Ogden CL, GrummerStrawn LM, 'et al'. CDC growth charts: United States advance data from vital and health statistics, no. 314. Hyattsville, MD: National Center for Health Statistics. 2000.

13. Kuczmarski RJ, Ogden CL, Guo S, Grummer SL, Flegal K, Mei Z. CDC growth charts for the United States: Methods and Development 2000.

14. Alredainy, R., \& Al Lami, F. Overweight and Obesity in A Sample of Primary School Children in Baghdad. Iraqi Academic Scientific Journal 2016; 15(4), 452-458.

15. Zekavat OR, Makarem AR, Shayan Z, Shojaee M, Karami MY. Obesity and overweight among primary school children in Iran. Minerva pediatrica. 2014 Dec;66(6):579-84.

16. Grummer-Strawn L, Krebs NF, Reinold CM. Use of World Health Organization and CDC growth charts for children aged 0-59 months in the United States.

17. Muthuri SK, Onywera VO, Tremblay MS, 'et al'. Relationships between parental education and overweight with childhood overweight and physical activity in 9-11 year old children: Results from a 12country study. PloS one. 2016 Aug 24;11(8):e0147746.

18. Ruiz M, Goldblatt P, Morrison J, 'et al'. Impact of low maternal education on early childhood overweight and obesity in Europe. Paediatric and perinatal epidemiology. 2016 May;30(3):274-84.
19. Vázquez-Nava F, Treviño-Garcia-Manzo N, Vázquez-Rodríguez CF, Vázquez-Rodríguez EM. Association between family structure, maternal education level, and maternal employment with sedentary lifestyle in primary school-age children. Jornal de pediatria. $2013 \mathrm{Apr}$;89(2):145-50.

20. Oddy WH. Infant feeding and obesity risk in the child. Breastfeeding review. 2012 Jul;20(2):7.

21. Estévez-González MD, Del Pino AS, Henríquez-Sánchez P, Peña-Quintana L, Saavedra-Santana P. Breastfeeding during the first 6 months of life, adiposity rebound and overweight/obesity at 8 years of age. International Journal of Obesity. 2016 Jan;40(1):10.

22. Rosiek A, Maciejewska NF, Leksowski K, Rosiek-Kryszewska A, Leksowski Ł. Effect of television on obesity and excess of weight and consequences of health. International journal of environmental research and public health. 2015 Aug;12(8):9408-26.

23. Graf C, Koch B, Dordel S, SchindlerMarlow S, Icks A, Schüller A, BjarnasonWehrens B, Tokarski W, Predel HG. Physical activity, leisure habits and obesity in first-grade children. European Journal of Cardiovascular Prevention \& Rehabilitation. 2004 Aug;11(4):284-90.

24. Cesani MF, Luis MA, Torres MF, Castro LE, Quintero FA, Luna ME, Bergel ML, Oyhenart EE. Overweight and obesity in schoolchildren from Brandsen and its relationship with socio-environmental characteristics of residence. Archivosargentinos de pediatria. 2010 Aug $1 ; 108(4): 294-302$.

25. BANIS HT, Varni JW, Wallander JL, 'et al'. Psychological and social adjustment of obese children and their families. Child: care, health and development. 1988 May;14(3):157-73. 